\title{
Benefit of Cow Urine, Milk, Ghee, Curd, and Dung Versus Cow Meat
}

\author{
Dirgha Raj Joshi ${ }^{1 *}$ and Nisha Adhikari ${ }^{2}$ \\ ${ }^{1}$ College of Pharmacy, Yonsei University, Republic of Korea \\ ${ }^{2}$ College of Pharmacy, Wonkwang University, Republic of Korea \\ *Corresponding Author: Dirgha Raj Joshi, College of Pharmacy, Yonsei University, Republic of Korea.
}

Received: July 18, 2019; Published: July 31, 2019

DOI: 10.31080/ASPS.2019.03.0360

\begin{abstract}
In world both cow urine and meat consuming people are enough. It is mostly directed by religious boundaries like Hindu don't eat cow meat and prefer cow urine, milk, curd, dunk, and ghee but Muslim and Christian can also eat cow meat with higher priority. Cow is regarded as mother in eastern culture. The urine of Cow is panacea of all disease so; it is a divine agent to treat migraine, asthma, psoriasis, diabetes, hypertension, eczema, heart attack, acidity, ulcer, constipation, menstrual problem, piles, cancer, arthritis, thyroid, prostate, burns, and many more. Also used as bio enhancer, to fix nitrogen level of soil, pesticide, antibacterial, anthelmintic, antifungal, larvicidal for fodder corps etc. The cow urine contains most of the needed micro elements for human, thus using it helps to balance needed trace minerals and other agents to make healthy and cure incurable diseases. Behind this it's ecofriendly without any bad effect it's very useful to human, animals, soil and the environment where we exist. Behind this various use and benefits of cow milk, dunk, curd, and ghee are reported. On the other hand many use as well as bad effect of consuming cow meat is also reported like mad cow disease, allergies, etc. This review will discuss about merit and demerit of consuming cow and its related products.
\end{abstract}

Keywords: Cow Urine; Cow Meat; Panchagawya; Cow Urine Therapy; Antibacterial; Antioxidant

\section{Introduction}

Cow being considered as a holey animal from ancient time in eastern philosophy [1-5]. Hindu religion placed cow as a mother position $[6,7]$. The milk constituent of the cow and the mother are similar, so they consider the cow as a mother. On the other hand, the urine of cow contains antibacterial [8], antifungal [9-11], antiviral, insecticidal $[12,13]$ etc. property which supports more about the use of cow urine. Similarly, the dunk of the cow also has antibacterial, antiseptic property and used as a fuel also for cooking foods as well as its burning fumes kills the insects, and other harmful organism, so used to clean the environment [13]. On the other hand, the people who belongs to the other religion specially the Muslim, Christian easily accept the cow as a source of protein by eating their meat [14-17]. So, they don't hesitate to kill the cow but the Hindu person its beyond humanity [17]. The people are divided in to two categories as, cow killing people and treating cow as a mother people. This critical review will provide a detail comparison and benefit of using the cow urine rather than the cow meat. When we kill a cow as a source of meat then its life ends there. On the other hand, if we consider cow as a source of milk, dung, urine, ghee, curd then we can get regular more benefit from it. Besides having individual nutritional value of meat and milk [18] if we compare the net benefit the later one will be far much more than the meat using [19]. The scientifically proved research now gives a better way of using the cow urine from the househ old, sanitation, fertilizer, insecticides, pesticides to a more advanced disease model from common disease to a cancer and more [20-24]. The Hindu literature Veda gives great value to cow, treating as a mother and a greater part of this universe for purifying the devils to impure airs and environments.

Biochemical analysis of cow urine

Many potent constituents which are almost needed to our body physiology were identified by the biochemical analysis of urine like sodium, sulfur, nitrogen, minerals, vitamins A, B, C, D, E, manganese, silicon, iron, chlorine, enzymes, magnesium, succinic, citric, phosphate, calcium salt, carbolic acid, creatinine, lactose, hormones etc, so having deficiency of these can be recovered by using cow urine $[13,20,25]$. The various fraction of cow urine via different solvents extraction signifies antioxidant and antimicrobial potency; it might be due to the above mentioned compositions [26-28]. Cow urine also promotes phagocytic activity to defense against bacterial infections, the synthesis of interleukine 1 and 2 [29, 30], IgA, IgG, IgM, T-lymphocytes thus promotes immunity [31]. Cow urine generally regarded as safe because $95 \%$ is water, $2.5 \%$ urea and remaining other $2.5 \%$ is mixture of above mentioned minerals, hormones and salts $[13,32]$. 
Traditional use of cow related products

From time immemorial cow is being a holey animal not only in the religious sense but in eastern culture they treat it as mother because it is feeding a whole family good diet through its milk and related products like ghee, butter and curd like a mother is doing for her children. The urine has its diverse use to treat various diseases as well as to maintain normal life and as fertilizer, pesticide etc. The dung is used as fertilizer, as fumigating agents to avoid mosquito, insects and other harmful organism and as an energy source to cook food etc [13]. Other various traditional use of cow urine is verified by scientific study as listed in Table 2 . The various use of cow related products are previously discussed in our vedic scriptures like Charak Samhita, Manu Smriti, Sushruta Samhita and recent few decade scientific study, published articles, developed formulations, patent etc. signifies the traditional use of cow and related products are worthwhile [25,28]. The Figure 1 shows the common traditional use of cow urine. Various synergistic activity of cow urine with different plants extract and other potential herbal plants are shown in Table $1[20,23]$.
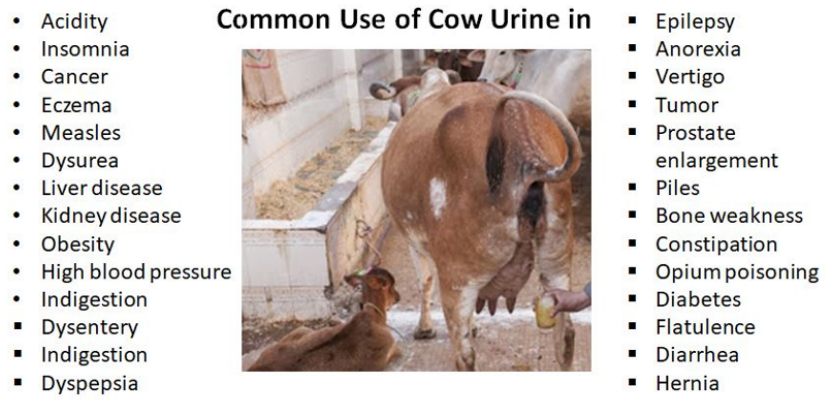

Figure 1: Common use of Cow Urine.

\begin{tabular}{|l|c|}
\hline \multicolumn{1}{|c|}{ Composition containing } & Indication \\
\hline $\begin{array}{l}\text { Urine, Kuraila and Neem bark, Vasaka and } \\
\text { Kaner leaves }\end{array}$ & Chronic leprosy \\
\hline $\begin{array}{l}\text { Cow urine, milk and tripala or Cow urine, } \\
\text { milk and loh bhasma }\end{array}$ & Anemia \\
\hline $\begin{array}{l}\text { Urine and Dhruhardi or Nimbuchal, and } \\
\text { Urine in severe condition }\end{array}$ & Leprosy \\
\hline $\begin{array}{l}\text { Urine, Mustard oil,Neem bark, and Soma- } \\
\text { pada bark }\end{array}$ & Epilepsy \\
\hline Urine, Ghee, Pepper, and Curd & Fever \\
\hline
\end{tabular}

Table 1: Traditional practice of cow urine with other medicinal valued one.

\begin{tabular}{|l|c|c|c|}
\hline SN & Use of Cow urine as & SN & Use of Cow urine as \\
\hline 1 & Antibacterial [8,27] & 10 & Bio enhancer [22,36] \\
\hline 2 & Antifungal [9-11] & 11 & $\begin{array}{c}\text { Chemotherapeutic potential } \\
{[24]}\end{array}$ \\
\hline 3 & Antiviral [37] & 12 & Anticancer [21] \\
\hline 4 & Anthelmintic [38] & 13 & Immunomodulator [39,40] \\
\hline 5 & Insecticide [12] & 14 & Antidiabetic [33,41,42] \\
\hline 6 & Fertilizer [43] & 15 & Antioxidant \\
& & $126,40,42,44,45]$ \\
\hline 7 & Antiseptic [12] & 16 & Antimicrobial [31, 34, 46] \\
\hline 8 & Wound healing [35] & 17 & Plant growth enhancer [47] \\
\hline 9 & Multi drug resistant & 18 & Lipid lowering activity [49] \\
\hline
\end{tabular}

Table 2: Diversified use of cow urine.

\section{Health benefits of Cow urine}

Many health benefits of consuming cow urine distillate or other processed form are reported [10,13,26,33-35]. The variation of different species of cow matter a lot in biological activities. The beneficial health effects of urine are due to its chemical constituents as discussed above in biochemical analysis of urine. The benefit of cow urine are not limited to human physiology but also as a fertilizer, antiseptic, other cleansing purposes, and many more. Below Table 2 shows the diversified use of cow Urine.

\section{Benefit of other cow product except meat}

The mainly universal acceptance is consumption of cow milk. The constituent of cow milk is nearly similar to human mother milk. Along with milk and urine the other processed product of milk are popular like curd, ghee, cheese, and dunk. Each has various benefits to the human body as well as to the environment which are reported in various scientific literatures. The crude or heated cow milk have different taste as well as varied risk and benefits [50]. The benefits of cow milk are shown in Figure 2. and the Figure 3 shows Panchagavya formulation.

\section{Cow Milk Benefits}

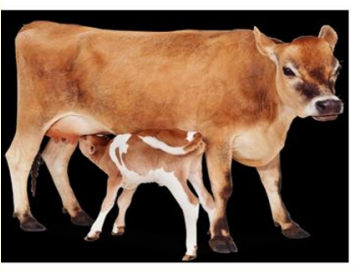

\footnotetext{
Improve immunity by increasing antioxidant Activity and decreasing inflammation - Improve liver function by promoting export of lipid in the form of lipoprotein from liver - Promote milk protein synthesis so increase milk production

> Contain calcium, phosphorus, iron and other minerals which balance our body function $>$ Good for infants, kids and adults and Improve bone function and nourishes skin etc.
}

Figure 2: Benefits of Cow Milk. 

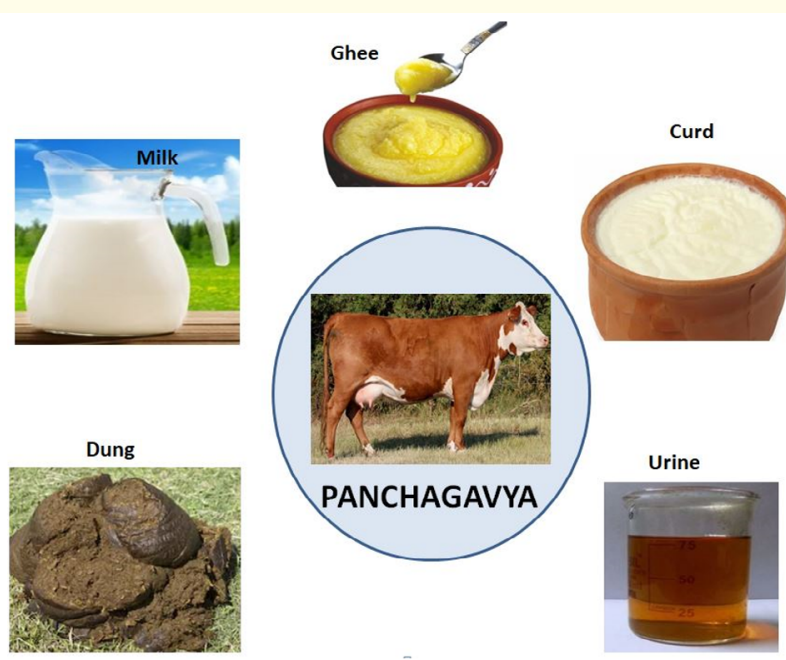

Figure 3: Panchagavya formulation constituents.

\section{Common Disease from Cow meat eating}

Mad cow disease: IIt is Bovine spongiform encephalopathy (BSE) [51], which is a transmissible spongiform encephalopathy and the fatal neurodegenerative disease in cattle which can passed to human subject by eating infected flesh [52-54]. The spongiform degeneration of the brain and spinal cord caused by BSE makes animal to die in near future via serious other health complications. The BSA has 2.5 to 5 years of incubation period so, it's hard to identify immediate after consuming infected meat [55]. Prion is a misfolded protein that cause BSE [56]. The frequent way of transmission to human by eating contaminated brain, spinal cord, or digestive tract. The infecting agent is highly concentrated in nervous tissue and be available virtually to all tissue throughout the body of cow including the blood [57]. reduced the latter as well as apoptotic and necroptotic cell death markers and the ROS and RNS moieties [unpublished findings].We believe our findings on programmed cell death and autophagic proteins, if found in humans imbibing heroin-fentanyl mixtures, may go a "long-way" towards indicating why cognitive and memory processes become severely impaired in the abusers of these very dangerous opiates.

After transmitted to human it is known as a new variant Creutzfeldt-jakob disease (vCJD or nvCJD) [58]. By June 2014 it had killed 177 people in UK. The prion, a misfolded protein in brain cause native cellular prion protein to deform to an infectious state which go further to exponential cascade and leads to aggregation of proteins which then forms a dense plaque fiber with microscopic

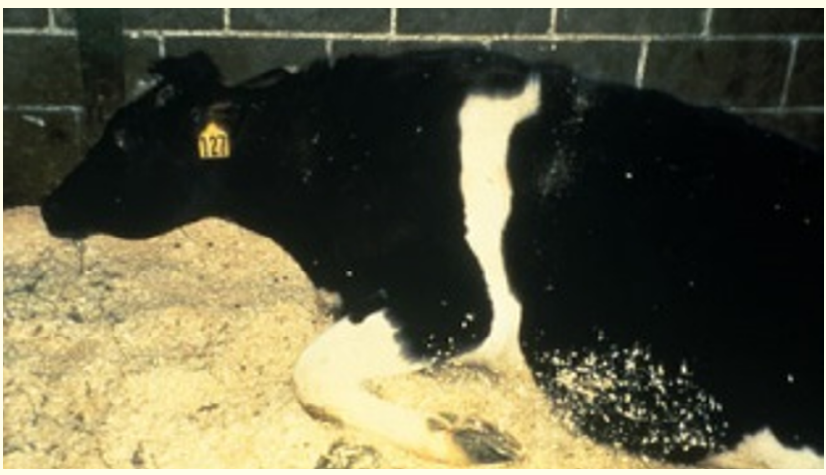

Figure 4: A cow with BSE that lost its ability to stand.

holes then the degeneration of physical and mental ability of brain and ultimately death. The public perception towards this disease becomes diverse [59].

Beside this consuming meat is related to various other health's complications including the short to chronic diseases [60]. The choice of food [61] and eating habits played a crucial role in human health [62-64]. The quality of meat is largely determined by the eating habit of cow, its surrounding, disease conditions and many more [65-70]. So the concern about the healthier meet should be of prime concern $[71,72]$. The present consumption, processing, and transportation of meat is changed to the past and may more different in future [73-75].

\section{Adverse effect of cow urine}

Based on what kinds of food the cow is consuming, its environmental effects, health conditions and the nature of the consuming person etc. can determine the adverse effects associated with cow urine. Although these days distillated cow urine consuming is growing very fast but still in village area direct fresh consumption of cow urine is common. To get clean urine we need to collect the urine at middle part of urination and the clean collection vessel, properly washed clean vagina of cow will helps to prevents so many contaminations. It has strong pharmacological effects as mentioned in above table so the dose should be controlled to get optimum benefits and fewer side effects. The common effects associated with consuming cow urine include itch, soreness, diarrhea, pain, fever and allergy etc. Some dog [76] mice model of cow urine toxicity are observed $[77,78]$. 
Other complications using cow products and overcoming action

The feeding of cow milk to infants may have potency to lose GI blood and decrease the iron contents [79]. Some people may have cow milk allergy [80]. To decrease the fat contents in milk various processes were carried out to remove the fat. Modification of milk fat contents to promote fatty acids usefulness to the human health become popular now [81] and many other action are playing great role for making more nutritional and quality meat and milk products [82]. In this open market people sometime contaminate the cow milk with other animal milk like buffalo, goat, sheep's etc. To detect the adulteration a multiples polymerase chain reaction can be performed [83].

\section{Environmental effects of meat consumption}

Either it is from eating cow meat or any other animals, birds etc. they are responsible for causing environmental changes mostly the green house effects [84-86]. The meat is ready source of energy so it can undergo fast decomposition and causes many correlated problems to the environment or the consumers.

\section{Conclusion}

Although the large number of population is consuming milk, urine as well as meat of cow, the restriction of religion leads sometime the disturbance among religion people. Much scientific evidence is proving the benefit of vegetarian over meat eating. If we treat cow as a source of milk, dunk, ghee, curd, and urine we can use a single cow for a long time as well as it benefit are far more than consuming it meat and make limited the cow for one time meat eating which will close other door. It's hard to tell someone to eat this or not to eat that but the core things is we need to analyze the risk benefit ratio. Like consuming the beef leads death of many people by mad cow disease.

\section{Acknowledgement}

We heartily acknowledge Yonsei University, College of Pharmacy and Wonkwang University, College of Pharmacy for providing space and needed things to prepare this manuscript.

\section{Bibliography}

1. Korom FJ. "Holy cow! The apotheosis of Zebu, or why the cow is sacred in Hinduism". Asian Folklore Studies 59.2 (2000): 181-203

2. Brown WN. "The sanctity of the cow in Hinduism". The Madras University Journal 28 (1957): 29-49.
3. Simoons FJ. "The purificatory role of the five products of the cow in Hinduism". Ecology of Food and Nutrition 3.1 (1974): 21-34.

4. Robinson C and D Cush. "The sacred cow: Hinduism and ecology". Journal of Beliefs and Values 18.1 (1997): 25-37.

5. Adcock C. "Sacred cows and secular history: Cow protection debates in Colonial North India. Comparative Studies of South Asia, Africa and the Middle East 30.2 (2010): 297-311.

6. Chapple CK and ME Tucker. "Hinduism and ecology". 2000: Harvard University Press Cambridge.

7. Klostermaier KK. "A survey of Hinduism". SuNY Press (2007).

8. Sathasivam A., et al. "Antimicrobial activities of cow urine distillate against some clinical pathogens". Global journal of pharmacology 4.1 (2010): 41-44.

9. Rakesh K., et al. "Antifungal activity of cow urine against fungal pathogens causing rhizome rot of ginger". Environment and Ecology 31.3 (2013): 1241-1244.

10. Deshmukh SS., et al. "Ingole, Antifungal activity of cow urine". IOSR Journal of Pharmacy 2.5 (2012): 27-30.

11. Kekuda PT., et al. "Antifungal effect of cow urine extracts of selected plants against Colletotrichum capsici isolated from anthracnose of chilli". International Journal of Agriculture and Crop Sciences 7.3 (2014): 142.

12. Mandavgane S., et al. "Development of cow urinebased disinfectant". (2005).

13. Mohanty I., et al. "Diversified uses of cow urine". International Journal of Pharmacy and Pharmaceutical Sciences 6.3 (2014): 20-22.

14. Chigateri S. "Glory to the Cow': cultural difference and social justice in the food hierarchy in India". South Asia: Journal of South Asian Studies 31.1 (2008): 10-35.

15. Robbins P. "Meat matters: cultural politics along the commodity chain in India". Ecumene 6.4 (1999): 399-423.

16. Seleshe S., et al. "Meat consumption culture in Ethiopia". Korean Journal for Food Science of Animal Resources 34.1 (2014): 7-13. 
17. Harris M. "Cows, pigs, wars, and witches: the riddles of culture. Vintage (1989).

18. Tomé D., et al. "Nutritional value of milk and meat products derived from cloning". Cloning and Stem Cells 6.2 (2004): 172177.

19. Ornish D. "Holy cow! What's good for you is good for our planet: comment on "Red meat consumption and mortality". Archives of internal medicine 172.7 (2012): 563-564.

20. Jain N., et al. "Efficacy of cow urine therapy on various cancer patients in Mandsaur District, India-A survey". International Journal of Green Pharmacy (IJGP) 4.1 (2010).

21. Dhama K., et al. "Anti-cancer activity of cow urine: current status and future directions". International Journal of Cow Science 1.2 (2005): 1-25.

22. Khanuja SPS., et al. "Use of bioactive fraction from cow urine distillate ('go-mutra') as a bio-enhancer of anti-infective, anticancer agents and nutrients". Google Patents (2005).

23. Khanuja SPS., et al. "Pharmaceutical composition containing cow urine distillate and an antibiotic". Google Patents (2002).

24. Randhawa GK and R Sharma. "Chemotherapeutic potential of cow urine: A review". Journal of intercultural ethnopharmacology 4.2 (2015): 180.

25. Kumar A. "A study on various biochemical constituents in the urine of cow, buffalo and goat". MV Sc. thesis submitted to the CSA University of Agriculture and Technology (2001).

26. Jarald E., et al. "Antioxidant and antimicrobial activities of cow urine". Global Journal of Pharmacology 2.2 (2008): 20-22.

27. Sarsar V., et al. "Evaluation of antibacterial activity of photoactivated cow urine against human pathogenic strains". Environ Exp Biol 11 (2013): 201-3.

28. Achliya G., et al. "Antimicrobial activity of different fractions of cow urine". Indian J Nat Prod 20 (2004): 14-6.

29. Singla S and R Garg. "Cow urine: An elixir". Innov J Ayurved Sci 1.3 (2013): 31-35.

30. Chauhan R. "Panchgavya Therapy (Cowpathy): Current status and future directions". The Indian Cow: The Scientific and Economic Journal 1.1 (2004): 3-7.
31. Kumar S. "Analysis of Cow's Urine for Detection of Lipase Activity and Anti-Microbial Properties". J Pharm Biol Sci 7.1 (2013): 01-08.

32. Bhadauria H. "Gomutra-Ek Chamatkari Aushadhi (Cow urineA Magical Therapy)". (2002).

33. Jarald EE., et al. "Antidiabetic activity of cow urine and a herbal preparation prepared using cow urine". Pharmaceutical biology 46.10-11 (2008): 789-792.

34. Ahuja A., et al. "Antimicrobial activities of cow urine against various bacterial strains". Int J Recent Adv Pharm Res 2.2 (2012): 84-87.

35. Sanganal JS., et al. "Effect of cow urine on wound healing property in Wister Albino Rats”. Veterinary world 4.7 (2011): 317.

36. Randhawa G. "Cow urine distillate as bioenhancer". Journal of Ayurveda and Integrative Medicine 1.4 (2010): 240.

37. Dhama K., et al. "Panchgavya (Cowpathy): an overview". International Journal of Cow Science 1.1 (2005): 1-15.

38. Nishanth B., et al. "Cow urine concentrate: a potent agent with antimicrobial and anthelmintic activity". Journal of Pharmacy Research 3.5 (2010): 1025-1027.

39. Banga R., et al. "Cow urine and immunomodulation: An update on cowpathy". International Journal of Cow Science 1.2 (2005): 26-29.

40. Gosavi D., et al. "Immunomodulatory and antioxidant effect of gomutraark in rats". J Mahatma Gandhi Inst Med Sci 16 (2011): 37-41.

41. MP G., et al. "Antidiabetic potential of cow urine in streptozotocin-induced diabetic rats". 6.1 (2011): 8-13.

42. Sachdev DO., et al. "Evaluation of antidiabetic, antioxidant effect and safety profile of gomutra ark in Wistar albino rats". Ancient science of life 31.3 (2012): 84.

43. Langmeier M., et al. "Nitrogen fertilizer value of cattle manure applied on soils originating from organic and conventional farming systems". Agronomie 22.7-8 (2002): 789-800.

44. Athavale A., et al. "Evaluation of in-vitro antioxidant activity of panchagavya: a traditional ayurvedic preparation". Int J Pharm Sci Res 3 (2012): 2543-9. 
45. Lavania M., et al. "In vitro study of lipid peroxidation and free radical scavenging activity of cow urine". European Food Research and Technology 232.4 (2011): 703-711.

46. Minocheherhomji FP and BM Vyas. "Study of the antimicrobial activity of cow urine and medicinal plant extracts on pathogenic human microbial strains". Int J Adv Pharm Biol Chem 3 (2014): 836-40.

47. Jandaik S., et al. "Efficacy of cow urine as plant growth enhancer and antifungal agent". Advances in Agriculture 2015. (2015).

48. Rajapandiyan K., et al. "Azadirachta indica-cow urine extract, a novel controlling agent towards Clinically significant Multi Drug Resistant Pathogens". Journal of Applied Pharmaceutical Science 1.10 (2011): 17.

49. Manubhai CH., et al. "Lipid-lowering activity of Cow urine ark in guinea pigs fed with a high cholesterol diet". Avicenna Journal of Phytomedicine 4.5 (2014): 354.

50. Claeys WL., et al. "Raw or heated cow milk consumption: Review of risks and benefits". Food Control 31.1 (2013): 251262.

51. Wilesmith JW., et al. "Bovine spongiform encephalopathy: epidemiological studies". The Veterinary Record 123.25 (1988): 638-644

52. Foster J., et al. "Transmission of bovine spongiform encephalopathy to sheep and goats". The Veterinary Record 133.14 (1993): 339-341.

53. Collinge J. "Human prion diseases and bovine spongiform encephalopathy (BSE)”. Human Molecular Genetics 6.10 (1997): 1699-1705.

54. Smith PG and R Bradley. "Bovine spongiform encephalopathy (BSE) and its epidemiology". British Medical Bulletin 66.1 (2003): 185-198.

55. Scott MR., et al. "Compelling transgenetic evidence for transmission of bovine spongiform encephalopathy prions to humans". Proceedings of the National Academy of Sciences 96.26 (1999): 15137-15142.

56. Paramithiotis E., et al. "A prion protein epitope selective for the pathologically misfolded conformation". Nature Medicine 9.7 (2003): 893.
57. Brown P. "BSE: The final resting place". The Lancet 351.9110 (1998): 1146-1147.

58. Will R., et al. "A new variant of Creutzfeldt-Jakob disease in the UK". The Lancet 347.9006 (1996): 921-925.

59. Schlenker W and SB Villas-Boas. "Consumer and market responses to mad cow disease". American Journal of Agricultural Economics 91.4 (2009): 1140-1152.

60. Feskens EJ., et al. "Woudenbergh, Meat consumption, diabetes, and its complications". Current Diabetes Reports 13.2 (2013): 298-306.

61. Westhoek H., et al. "Food choices, health and environment: Effects of cutting Europe's meat and dairy intake". Global Environmental Change 26 (2014): 196-205.

62. Singer P and J Mason. "The ethics of what we eat: Why our food choices matter". Rodale Books (2007).

63. Simon DR. "Meatonomics: How the rigged economics of meat and dairy make you consume too much-and how to eat better, live longer, and spend smarter". Conari Press (2013).

64. Walker P., et al. "Public health implications of meat production and consumption". Public Health Nutrition 8.4 (2005): 348-356.

65. Kemp R. "Genetics of meat quality in cattle". in Proc. 5th World Congr. Genet. Appl. Livest. Prod. (1994).

66. Scollan N., et al. "Innovations in beef production systems that enhance the nutritional and health value of beef lipids and their relationship with meat quality". Meat Science 74.1 (2006): 17-33.

67. Mapiye C., et al. "The labile lipid fraction of meat: From perceived disease and waste to health and opportunity". Meat Science 92.3 (2012): 210-220.

68. Van Wezemael L., et al. "European consumer preferences for beef with nutrition and health claims: A multi-country investigation using discrete choice experiments". Food Policy 44 (2014): 167-176.

69. Webb E and H O'neill. "The animal fat paradox and meat quality". Meat Science 80.1 (2008): 28-36. 
70. Cordain L., et al. "Origins and evolution of the Western diet: health implications for the 21st century". The American Journal of Clinical Nutrition 81.2 (2005): 341-354.

71. Jiménez-Colmenero F., et al. "Healthier meat and meat products: their role as functional foods". Meat Science 59.1 (2001): 5-13.

72. Decker EA and Y Park. "Healthier meat products as functional foods". Meat Science 86.1 (2010): 49-55.

73. Goodwin J and C Shoulders. "The future of meat: A qualitative analysis of cultured meat media coverage". Meat Science 95.3 (2013): 445-450.

74. Gregory NG and T.Grandin. "Animal welfare and meat production". CABI (2007).

75. Wu X., et al. "Production of cloned transgenic cow expressing omega-3 fatty acids". Transgenic Research 21.3 (2012): 537543.

76. Elegbe R and D Oyebola. "Cow's urine poisoning in Nigeria: cardiorespiratory effects of cow's urine in dogs". Transactions of the Royal Society of Tropical Medicine and Hygiene 71.2 (1977): 127-132.

77. Oyebola D and R Elegbe. "Cow's urine poisoning in Nigeria. Experimental observations in mice". Tropical and Geographical Medicine 27.2 (1975): 194-202.

78. Oyebola D. "Cow's urine concoction: its chemical composition, pharmacological actions and mode of lethality". African Journal of Medicine and Medical Sciences 12.1 (1983): 57-63.

79. Ziegler EE., et al. "Cow milk feeding in infancy: further observations on blood loss from the gastrointestinal tract". The Journal of Pediatrics 116.1 (1990): 11-18.

80. Bishop J., et al. "Natural history of cow milk allergy: clinical outcome". The Journal of Pediatrics 116.6 (1990): 862-867.

81. Lock AL and DE Bauman. "Modifying milk fat composition of dairy cows to enhance fatty acids beneficial to human health". Lipids 39.12 (2004): 1197-1206.

82. Sretenović L., et al. "Nutritional factors influencing improvement of milk and meat quality as well as productive and reproductive parameters of cattle". Biotechnology in Animal Husbandry 23.5-6-1 (2007): 217-226.
83. Bottero MT., et al. "A multiplex polymerase chain reaction for the identification of cows', goats' and sheep's milk in dairy products". International Dairy Journal 13.4 (2003): 277-282.

84. Goodland R and J Anhang. "Livestock and climate change: What if the key actors in climate change are... cows, pigs, and chickens?". (2009).

85. McMichael AJ., et al. "Food, livestock production, energy, climate change, and health". The Lancet 370.9594 (2007): 12531263.

86. Friel S., et al. "Public health benefits of strategies to reduce greenhouse-gas emissions: food and agriculture". The Lancet 374.9706 (2009): 2016-2025.

\section{Volume 3 Issue 8 August 2019}

(C) All rights are reserved by Dirgha Raj Joshi and Nisha Adhikari. 